\title{
REVIEW
}

\section{Dispersal of marine meiofauna: a review and conceptual model explaining passive transport and active emergence with implications for recruitment}

\author{
Margaret A. Palmer \\ Department of Zoology, University of Maryland, College Park, Maryland 20742, USA
}

\begin{abstract}
A number of recent studies have shown that water-column processes exert an important influence on meiofaunal recruitment and colonization of new areas. This paper reviews those studies which have investigated the water-column occurrence of meiofauna and the subsequent settlement process. Two distinct patterns exist for recruitment via water-column pathways: active entry of meiofauna into the water and passive erosion of meiofauna from the sediments. A conceptual model is proposed in which 4 factors interact to determine whether active vs passive mechanisms are most important for a given community: taxonomic composition, hydrodynamics, aboveground structure, and disturbance. For the meiofauna of areas which are hydrodynamically benign and dominated by actice swimmers (e.g. seagrass beds), water-column recruitment should involve substrate choice through active swimming. In areas which are free of aboveground structure and more rigorous hydrodynamically (e. g. tidal flats, beaches) passive recruitment processes dominate and are modified by behaviors which may influence transport and settlement. In all habitats, structure probably acts to enhance active emergence to some extent while disturbance events may lead to increased suspension and possibly active emergence. Future directions are discussed with an emphasis on the need for the development and standardization of new methodologies which can be used in a variety of habitats.
\end{abstract}

\section{INTRODUCTION}

Recruitment of meiobenthic invertebrates has traditionally focused on the local addition of newborns to the sediments within a population or on the infaunal immigration of adult or juvenile colonists through the sediments to new areas (Swedmark 1963, McIntyre 1969). This emphasis on sediment pathways as the primary means for meiofaunal recruitment is no longer appropriate since a number of recent studies have shown quite convincingly that both adult and juvenile meiofauna are regularly found in the water column (e. g. Hagerman \& Rieger 1981). Therefore, despite the fact that meiofauna lack pelagic larvae, water column processes must exert an important influence on meiofaunal recruitment and colonization of new areas (Kern \& Bell 1984, Palmer \& Gust 1985). Even though most macrobenthic larvae which are competent to settle are larger than meiofauna (Warwick et al. 1986), the recruitment of both through water-column pathways is analogous (Butman 1986). Recruitment can be considered a 3-stage process depending on: (1) the availability of recruits; (2) the ability of these recruits to reach suitable settlement sites; and (3) the ability of these recruits to survive and become established once they reach the new habitat.

The degree to which active behavioral events and passive responses to the hydrodynamic regime influence these 3 stages of recruitment has been intensely debated for macrofaunal recruitment (e.g. Scheltema 1986, Butman 1987). Efforts to examine this issue for the meiofauna are needed since there is substantial evidence that 2 distinct patterns exist for water-column recruitment: (1) passive erosion of meiofauna from sed- 
iments with subsequent settlement back to the bottom (e. g. Hagerman \& Rieger 1981, Palmer \& Gust 1985) and (2) active entry of meiofauna into the water with subsequent settlement or active site selection (e. g. Hicks 1986, Walters 1987). The inferred importance of active versus passive mechanisms may be related, in part, to differences in sampling methodologies used in these studies. More importantly, however, habitat differences may influence mode of entry into the water column. The focal point of this paper will be the identification of those basic features which may promote active versus passive movement of meiofauna into the water.

Early studies assumed that meiofauna had low rates of dispersal and were basically sediment-bound (Sterrer 1973). The fact that meiofauna are found to enter the water both passively and actively requires consideration of the adaptive significance of these water column excursions. Possible short-term advantages of meiofaunal emergence include finding mates and copulating (Hicks 1988), avoiding crowded conditions, i. e. density-dependent migration (Service \& Bell 1987), and feeding in the benthic boundary layer (Decho 1986), in surficial sediments, or near structures where food resources may be enhanced (Thistle et al. 1984, Eckman 1985). The major disadvantages of entering the water-column include transport to unfavorable areas (Paimer \& Gust 1985) and possible increased predation by epibenthic and natant predators due to the enhanced visibility/availability of meiofauna once they are above the sediments (Robertson \& Howard 1978, Magnhagen \& Widerholm 1982, Marinelli \& Coull 1987, Palmer 1988). In some cases, water-column entry in the presence of predators (especially infaunal) may be advantageous particularly if emigration occurs at night when predatory risks may be lower (Ambrose $1984)$.

Water-column modes of meiofaunal recruitment may be augmented by migration through the sediments. A study by Chandler \& Fleeger (1983) was carefully designed to determine whether colonization into new areas occurred via the water column or via sediment immigration. Colonization of copepods was almost entirely from the water, yet nematodes relied to some extent on infaunal (sediment) movement. One key factor in such experiments is the size of the defaunated area and the distance meiofauna must travel to recolonize an area (Hockin \& Ollason 1981). Studies have shown that when large areas are defaunated, meiofaunal colonization can occur within hours (e. g. Sherman \& Coull 1980). It is highly unlikely that animals 200 to $800 \mu \mathrm{m}$ in length could burrow distances of meters in only hours. For example, burrowing rates of the meiobenthic foram Ammonia beccari have been measured using time-lapse cinematography (K. Wet- more pers. comm.). These animals migrate through sediments at rates of ca $4 \mathrm{~mm} \mathrm{~h}^{-1}$, yet Sherman \& Coull (1980) found that this species colonized azoic areas $3 \mathrm{~m}$ away within hours. In such cases, one can only conclude that meiofaunal recruitment occurred primarily via the water column. This conclusion was recently confirmed by the experiments of Savidge \& Taghon (1988). Because of its obvious importance as a mechanism for meiofaunal recruitment, the water-column mode will be focused on here.

In this paper my purpose is to: (1) review those studies which have investigated the water-column occurrence of meiofauna; (2) address the issue of active versus passive entry of meiofauna into the water by offering evidence that at least 4 factors influence the relative importance of behavioral entry versus passive transport; (3) review what little is known about settlement, emphasizing future goals in this area; and (4) discuss what broad generalizations can be made concerning recruitment of meiofauna via water-column pathways. Throughout, I will be focusing on sediment meiofauna which can be collected using standard coring methods.

\section{MEIOFAUNA IN THE WATER-COLUMN}

The earliest studies which investigated the occurrence of meiofauna in the water column were done in beach and estuarine habitats. In general, these studies suggested that passive processes were responsible for the large number of meiofauna in the water. Hagerman \& Rieger (1981) found that interstitial meiofauna of North Carolina shores were suspended into the water column by shoaling and breaking waves and that ca $80 \%$ of the variation in suspended nematode densities was correlated with changes in the mean onshoreoffshore component of local wind velocity. Similarly, Palmer \& Brandt (1981), working in a South Carolina estuary, found that mud-dwelling meiofauna had lowest abundances in the sediments at times during the tidal cycle when highest current velocities were measured. These meiofauna were suspended into the water column by tidal currents, such that greatest abundances in the water were found when friction velocity increased (Palmer \& Gust 1985). Friction velocity $\left[u_{\star}=(\tau / \rho)^{1 / 2}\right.$ where $\tau=$ shear stress, $\rho=$ fluid density $]$ is an expression of shear stress or the erosive force imparted by flowing water on the bottom sediments and meiofauna (see Wimbush \& Monk 1970 or Bowden 1978 for discussions of boundary layer flows). If meiofauna were entering the water column as passive particles, then their erosion should be controlled by friction velocity. Since Palmer \& Gust (1985) found that friction velocity was statistically the single most impor- 
tant factor in explaining variation in the number of meiofauna in the water, the mechanism for watercolumn entry from these unvegetated mudflats was passive transport. This conclusion was further supported by the absence of diel or lunar periodicities in the water-column occurrence of meiofauna in this study and supported by the results of previous experiments (Palmer 1984) which showed that regardless of time of day or tidal stage, fauna rarely entered the water column by active means. For those animals which exhibited any activity on the sediment surface, surface trips occurred only when flow was greatly reduced with animals quickly burrowing into the sediment as flow was increased.

Fleeger et al. (1984) also investigated the occurrence of estuarine meiofauna in the water column. Their study was conducted in intertidal vegetated areas in a Louisiana salt marsh and, thus, differed from the studies discussed above which were all completed in level, sandy or muddy areas free of aboveground structure. Fleeger et al. found that nematodes and the dominant sediment-dwelling copepod species had highest abundances in the sediments at low tide (no water cover) and lowest abundances at ebb tide (greatest flows); a pattern suggesting passive erosion. In addition to sampling the sediments, they deployed solid-sided emergence traps to collect fauna which had moved at least $8 \mathrm{~cm}$ up into the water. The predominant fauna collected in the water were zooplankton yet meiofauna were also collected and in higher numbers when flows were reduced, a pattern suggesting active emergence. Fleeger et al. expressed surprise that more meiobenthic species were present in traps at times when flows were reduced (a pattern they a priori expected only for emergent fauna known to vertically migrate). Even though their overall emphasis was on the passive movement of meiofauna from the sediments, they did provide evidence of possible active emergence... a first for estuarine meiofauna. Fleeger et al. point out that since traps were $8 \mathrm{~cm}$ off the bottom, meiofauna moving close to the sediment-water interface would not have been collected.

Recent studies have shown that not only is active emergence possible but that meiofauna dispersal from seagrass beds is primarily an active process (Hicks 1986, Walters \& Bell 1986). In these studies, meiofauna in the water were collected using plastic or polyvinylchloride emergence traps in which the base was inserted into bottom sediments. These emergence traps were designed to prevent most water flow; however, mesh-covered ports in the sides did prevent stagnation and allowed for water exchange (Hicks pers. comm). This design ensured that organisms caught in the traps must have migrated actively. Walters \& Bell (1986) found that of 28 species of copepods that were found regularly in the sediment, 19 species were also found to migrate vertically up into the water. Migrations were primarily during night-time and there was no evidence of tidal periodicity in emergence.

The study of Hicks (1986) focused primarily on the seagrass fauna themselves and emphasized the agility with which these fauna moved within the water near grassblades. He estimated that 3 to $13 \%$ of the available fauna (sediment + blade fauna) migrated. Only one species found in substantial numbers in traps was not a phytal species, suggesting that only a small fraction of sediment meiofauna migrated. Since the emergence traps were placed directly over rather than between grassblades, the origin of individual migrants could not be unambigiously determined; however, based on habitat-specific species information, an estimated $2.6 \%$ of sediment-dwelling copepods migrated. There was no diurnal component to migration but Hicks suggested that, based on samples of blades and subcanopy sediments, there was a tidal component to migration. Verification of the latter was presented by Bell et al. (1988) and an attempt was made to elucidate the exact timing of migrations during high water. They concluded that discrete swimming peaks within high tide occurred for various New Zealand species; however, because field traps and the laboratory protocol removed flow during the high water observations the results are difficult to interpret. With flow minimized in the traps, deployment at flood versus slack versus ebb would only test for endogenous emergence rhythms, not emergence associated with flow conditions.

Since studies have shown that meiofaunal swimming and surface-crawling behaviors are influenced by flow (see section on Hydrodynamics), conclusions that large numbers of meiofauna emerge based on studies which utilize emergence traps that remove or greatly reduce flow can only be applied to similar field conditions, i.e. slack water. Currents are generally reduced in these seagrass habitats due to the baffling effect of grass blades (Bell, Hicks \& Walters pers. comm.). Additionally, Tampa Bay does experience a low tidal range (Bell et al. 1988) suggesting only weak tidal currents; however, this does not preclude significant winddriven currents. The New Zealand site has a tidal range of $1.25 \mathrm{~m}$ (Bell et al. 1988) and presumably associated tidal currents, although no hydrodynamic data were presented.

\section{FACTORS INFLUENCING WATER-COLUMN ENTRY}

Clearly, the studies to date have provided evidence that passive processes exert a strong influence on the occurrence of meiofauna in the water, but active behavioral emergence can also occur. Numerous fac- 
tors may influence when and how many meiofauna are in the water column. For example, absolute numbers in the water may be related to abundances of meiofauna in the sediment and, in fact, density-dependent emergence has been suggested for species which actively enter the water column (Service \& Bell 1987). This paper will focus on the factors which may determine if entry is active or passive and not review the factors which influence the number of meiofauna in the water.

I suggest that at least 4 factors influence entry mode: taxonomic composition, hydrodynamics, aboveground structure and disturbance. Some of these factors, such as community composition (both major taxa and species), are well known to influence recruitment and colonization modes. Other factors, such as disturbance, have not been extensively studied in relation to recruitment and, thus, require some speculation.

\section{Taxonomic composition}

Free-living nematodes are the dominant members of most marine meiofauna communities, followed by harpacticoid copepods and then by a suite of other taxa including foraminiferans, ostracods, turbellarians, gastrotrichs, kinorhynchs, juvenile bivalves and polychaetes (Coull \& Bell 1979). These taxa are not found in the water columm in direct proportion to their sediment abundances (Bell \& Sherman 1980, Sibert 1981). The fauna most commonly found in the water are those which are good swimmers or are particularly susceptible to passive suspension. The latter would include those with a tendency to reside near the sediment surface and those with morphological constraints or behavioral characteristics which prevent them from maintaining contact with the sediment when flows exceed thresholds necessary to cause erosion (Palmer \& Gust 1985).

Copepods typically reside in the uppermost sediment layers and many are good swimmers (Hauspie \& Polk 1973, Fleeger 1980). Both of these factors explain why copepods are the meiobenthic taxa most commonly found in the water column (Sibert 1981, Palmer \& Gust 1985, Walters \& Bell 1986); however, residence in surficial sediment layers by good-swimmers does not necessarily mean they suffer enhanced passive erosion. Indeed, strong swimmers are more likely to successfully burrow into the sediments as flow increases and thus avoid transport (e.g. the copepod Microarthridion littorale: Palmer 1984). Turbellarians are also strong swimmers which frequent the sediment surface and the water (Hagerman \& Rieger 1981) but are able to reenter the sediment and avoid transport when flows increase (Palmer 1986). Conversely, benthic foraminiferans have no swimming abilities and are partic- ularly susceptible to erosion and suspension (Sherman \& Coull 1980). Many nematodes reside deeper in the sediments than copepods, some migrate downward if flow is present (Palmer \& Molloy 1986, Fegley 1987), and because nematodes possess only longitudinal muscles, most species are poor swimmers (Hopper \& Meyers 1966, although see Jensen 1981). Despite their high sediment abundances, nematodes occur in comparatively low abundances in the water column because they avoid the surficial sediment layers (Sibert 1981. Jacobs 1984). Other meiobenthic taxa which are rare in the water column include non-swimming and deep-borrowing species of ostracods, kinorhynchs, and gastrotrichs (Hagerman \& Rieger 1981, Palmer 1984).

At the species level, one would also expect to see differences in abundances in the water column due to behavioral and morphological variations. For example, of those harpacticoids which actively enter the water, certain species regularly make excursions while others do not (Walters \& Bell 1986). Sediment-dwelling harpacticoid copepods which have been reported as abundant in the water column due to active or passive processes include representatives from the following genera: Heterolaophonte, Paralaophonte, Normanella, Mesochra, Enhydrosoma, Diosaccus, Stenhelia, Schizopera, Bulbamphiascus, Ectinosoma, Zausodes, Longipedia, Metis and Paradactylopodia (Hagerman \& Rieger 1981, Palmer \& Gust 1985, Hicks 1986, Walters 1987). Some species which are caught in emergence traps in the field, such as Metis holothuriae, are known from laboratory studies to be strong swimmers that actively enter the water column (Walters 1987). Bell et al. (1987) suggest a potentially useful approach to predict which copepod species will remain in the sediments and which will migrate, based on morphometry of the first pereopod. Species which are relatively poor swimmers, such as Enhydrosoma propinquum, are believed to be found in the water column due to their residence in surficial sediments and high susceptibility to passive transport (Palmer 1984).

Nematodes which have been reported as abundant in the water include representatives from the following genera: Metachromadora, Chromadorita, Ptycholaimellus, and Prelionema (Bell \& Sherman 1980, Hagerman \& Rieger 1981, Jensen 1981, Eskin \& Palmer 1985). Metachromadora spp. have been found to reside near or at the sediment surface (Platt 1977, Blome 1983), leading Warwick \& Gee (1984) and Eskin \& Palmer (1985) to suggest that the high abundances and tidal periodicities of $M$. vivipara, $M$. chandleri, and $M$. obesa in the water column were due to passive suspension during periods of high current flow. Few data exist at the species level for other meiobenthic taxa which occur in the water column; however, Hagerman \& Rieger (1981) do provide some information for the tur- 
bellarian and gastrotrich fauna found suspended above a sandy bottom at one locality in North Carolina.

Clearly, meiobenthic species exhibit sufficient differences in their lifestyles and morphologies that the relative importance of active versus passive water column modes of recruitment will vary between communities and even within a given meiofauna community. Thus, even though certain features of a habitat (e.g. hydrodynamic regime) can be associated with active recruitment modes, only those species which are capable of swimming will actively emerge. This means that attempts to predict recruitment requires some knowledge of the taxonomic composition of the community under study.

\section{Hydrodynamics}

There is ample evidence that meiofauna respond behaviorally to flow and are dispersed in the water column as a result of erosion and subsequent advection. Some studies have demonstrated that flow is primarily responsible for the passive entry of meiofauna into the water column from unvegetated mudflats, beaches, and estuarine creeks (Bell \& Sherman 1980, Hagerman \& Rieger 1981, Palmer \& Gust 1985). We also know that some meiofauna migrate within the sediments as flow increases. This was suggested by Boaden (1968) and Boaden \& Platt (1971). Crenshaw (1980) made numerous laboratory observations of beach meiofauna moving into interstices and secreting what he called mucus dams as flow was increased. A flume experiment by Palmer \& Molloy (1986) showed that such responses were more pronounced for certain taxa; foraminiferans and nematodes migrated downward 2 to $15 \mathrm{~mm}$ in flow compared to no-flow treatments. Adult and juvenile copepods remained within the top $2 \mathrm{~mm}$ regardless of flow; however, earlier studies (Palmer 1984) have shown that these meiobenthic copepods consistently burrow into the sediment (i.e. leave the sediment/water interface) as flow is increased. Rhoads et al. (1977) noted similar burrowing behaviors by meiofauna in response to increased flow. Likewise, Kern \& Taghon (1986) reported that several species of harpacticoids (including interstitial forms) which actively left the sediment surface did so only under conditions of no flow. Additionally, based on field studies in which flow was manipulated in situ, Fegley (1987) concluded that nematodes of intertidal sandflats respond to fast currents by moving deeper into sediments.

Thus, from a number of studies, it appears that meiofauna inhabiting many unvegetated sandy and muddy bottoms may avoid the benthic boundary layer at times of high flow in order to avoid passive transport but will frequent the sediment surface and enter the water column when flow is reduced. For meiofauna of vegetated habitats, Fleeger et al. (1984) found that higher numbers of meiofauna were caught in emergence traps at flood tide $\left[\bar{u}\right.$ (mean flow) $\left.=4 \mathrm{~cm} \mathrm{~s}^{-1}\right]$ versus ebb tide $\left(\bar{u}=15 \mathrm{~cm} \mathrm{~s}^{-1}\right)$, again suggesting that active emergence may be associated with low flow. No studies have examined the emergence of seagrass meiofauna under flow versus no-flow conditions; however, the seagrass systems studied do generally experience reduced flows and meiofauna do emerge in large numbers (Hicks 1986, Walters \& Bell 1986). Given the earlier references that even non-migratory copepods of sandflats and tidal creeks are more apt to spend time on the sediment surface rather than in the sediments when flow is reduced, given the impressive numbers of seagrass copepods regularly emerging, and given the finding that structure enhances emergence only when flow is reduced (see 'Aboveground structure'), low flow may indeed be a necessary condition for the active emergence of meiofauna.

\section{Aboveground structure}

A difference between seagrass systems and unvegetated estuarine systems which is even more obvious than their contrasting hydrodynamic regimes, is the enhanced habitat heterogeneity created by the grass blades themselves. Evidence that structure influences sediment-dwelling meiofauna mostly refers to belowground interactions, such as meiofaunal abundance around plant or seagrass shoots (e.g. Osenga \& Coull 1983). As pointed out earlier, the first evidence that meiofauna are found in the water in vegetated areas was provided by Fleeger et al. (1984) for Spartina alterniflora marshes. Their study was not, however, intended to address the effects of structure on watercolumn dispersal of meiofauna. Several other studies have provided indirect evidence that meiofaunal activity in the water is influenced by aboveground structure. For example, meiofaunal recruitment into areas denuded of fauna is influenced by the presence of artificial or natural structures that alter the flow regime (Eckman 1983, Kern \& Taghon 1986). These studies did not determine if structure-induced flow effects altered the erosion, transport, and settlement of the meiofauna or if active behavioral emergence was influenced by the structures.

Emergence in areas with structure may be common if the structure provides a needed resource for the migrating animals or if migration is advantageous for other reasons (see 'Introduction') and the structure reduces risks associated with entering the water. The presence of aboveground structures has been shown to 
decrease the risk of predation for both infauna (Woodin 1978, Blundon \& Kennedy 1982) and epifauna, including meiofauna (Heck \& Orth 1980, Coull \& Wells 1983). Furthermore, structures may serve as refuges from flow (Palmer 1986) since the downstream transport of fauna may be reduced if animals cling to structures or retreat into spaces between blades or along the boundary layer of the structures themselves (Statzner 1981, Silvester \& Sleigh 1985).

One study has specifically examined the effect of structure on active emergence, as well as the interactive effects of flow and structure on the downstream transport (drift) of meiofauna from both vegetated and unvegetated estuarine habitats (Palmer 1986). For the meiofauna from both habitats, emergence of adult and juvenile copepods increased significantly when structure was present and flow was absent. At 'low' flows, downstream transport of meiofauna from both sites was also greater when structure was present. Since these flows were below levels necessary for sediment erosion $\left(<u_{\star}\right.$-crit) , the drift of meiofauna resulted from active behaviours which involved emergence up into the water, emergence onto structures, or an orientation above the sediment surface into the benthic boundary layer which resulted in downstream transport. When flow was 'high' $\left(<u_{\star}\right.$-crit $)$, there were not such dramatic differences in drift between structure and no-structure treatments. Since this treatment was designed such that structure and no-structure treatments were exposed to the same potential for passive erosion, the finding of only small differences in drift between treatments suggests that structure does not act to enhance emergence if flow is elevated. Passive effects apparently dominate at higher flows. This supports the earlier suggestion that low flows promote active emergence.

Based on the finding that emergence of estuarine meiofauna is enhanced when vegetation is present and the documentation of large number of sediment-dwelling copepods emerging in seagrass habitats, it seems reasonable to suggest that, in general, natural structures promote emergence and reduce the advection of meiofauna. This generalization would be strengthened if similar studies done on seagrass meiofauna showed that clipping the grassblades (but not removing the fauna from the system) is associated with a decrease in the number of fauna emerging

\section{Disturbance}

The effect of sediment disturbance on water-column transport of meiofauna has not been studied extensively. It seems plausible that any disturbance event which leads to enhanced sediment resuspension should also result in an increase in suspended meiofauna and thus may influence the water-column availability of recruits. For example, a foraging flounder enhances sediment suspension and fiddler crabs release sediment plumes as they unplug their burrows. Such disturbance events are difficult to quantify or even observe in the field and may appear as 'noise' in data sets. We know that biological disturbance does influence meiofaunal abundance in the sediment (e.g. Reidenauer \& Thistle 1981) and macrofaunal disturbers should also influence meiofaunal drift. Studies on freshwater streams have shown that activities of predaceous macrofauna may result in significant increases in the downstream transport of benthic insects (Malmqvist \& Sjostrum 1987). Similarly, Palmer (1988) found that disturbance-induced drift of marine meiofauna was significantly increased when predaceous fish were present. The passive transport of meiobenthic copepods, foraminiferans, nematodes, and total meiofauna was approximately doubled due to fish activities.

The effect of disturbance on the entry of meiofauna into the water needs much more study. The possibility that meiofauna actively leave sediments which are exposed to disturbance has not been investigated; however, at least one study has shown that macrobenthos enter the water and emigrate in response to the feeding activities of predators (Ambrose 1984). Although disturbance has been established as a factor in determining the abundance of meiofauna in the water, broad generalizations concerning the importance of disturbance relative to flow and structure require detailed knowledge of the frequency and extent of these disturbances in the field and further observations of the meiofauna to determine if passive transport or emigration occurs. At best, one can say that disturbance needs to be investigated in recruitment studies which are performed in areas with an abundance of bioturbators or epibenthic macrofauna. Exclusion studies may be useful in such investigations and may, in fact, clarify the often confusing data which result from field studies on recruitment (e.g. Eckman 1983 ).

\section{THE SETTLEMENT PROCESS}

Thus far, I have concentrated on factors which control the availability of meiofauna in the water column. The actual settlement phase and subsequent establishment in the sedimentary environment have not been well studied. As pointed out earlier, numerous colonization studies have demonstrated that meiofauna repopulate areas in hours to days (e.g. Scheibel 1974 , Scheibel \& Rumohr 1979) and that recruits may travel 
great distances in the water (see review in Coull \& Palmer 1984). What factors determine where recruits settle is difficult to answer. Eckman (1983) suggested that meiofaunal settlement may be a passive process and thus controlled purely by hydrodynamics. He designed field experiments in which he altered the rates of fluid transport near the bed and then followed the pattern of faunal recruitment into the experimental areas. Although his results were complex, varying by date and between taxa, he did find that recruitment of some meiofauna generally followed a passive model.

Kern \& Taghon (1986) completed a similar series of experiments, which showed that meiobenthic copepods exhibited enhanced recruitment into areas where sediments accumulated. They found that recruitment was even greater in areas which were microbially enriched. Based on their experiments, which also produced highly variable results, they concluded that meiofaunal recruitment was largely a passive process but that behavior could modify final settlement patterns. Both the Eckman (1983) and Kern \& Tahon (1986) studies were done on intertidal sandflats subjected to fairly rigorous tidal flows ( $u_{\star}$ known to reach $1.0 \mathrm{~cm} \mathrm{~s}^{-1}$ and may exceed critical erosion velocity). Studies like these have not been performed on meiofauna communities in or near seagrass beds. Based on the work to date in seagrass habitats, one would expect a hydrodynamic model of settlement to have limited relevance. In seagrass areas flow is reduced, meiofauna communities are dominated by strong swimmers, and the grassblades (structure) may encourage emergence; thus, active habitat selection may be expected. Even in areas which experience turbulent tidal flows, active processes can not totally be discounted. Hannan (1984) stressed this point in her study of settlement patterns for the polychaete Mediomastus ambiseta. Although settlement of this animal was primarily a passive process, final settlement likely involved behaviors in which larvae may actively reject a location by swimming or remain close to the sediment-water interface where suspension is likely. Meiofauna may exhibit similar behaviors.

\section{GENERALIZATIONS}

Recruitment modes of the meiofauna appear complex, involving both active and passive components. A continuum along an active/passive axis exists with the meiofauna of different habitats, and even different species within a habitat, falling at different places along this continuum. Regardless of these complexities, some broad generalizations can be made. These generalizations represent a synthesis of findings from the diverse dispersal, recruitment, and colonization studies. The general model outlined below will certainly change in the future as new and creative studies on meiofauna recruitment continue to appear.

Both juvenile and adult meiofauna act as recruits in all habitats studied so far. Over large spatial scales (i.e. meters or more), recruitment via the water column seems universal in all habitats and is augmented to a lesser degree by infaunal immigration, particularly for poor-swimming or deep-burrowing meiofauna. The number of recruits in the water column is greatest at times when bottom shear is sufficient to cause erosion in unvegetated tidal creeks, beaches, and sandflats, and at dusk or night-time in some seagrass systems.

Estimates of the percentage of the bottom fauna in the water column have been calculated for the meiofauna of different habitats; however, comparisons of these percentages are problematic. First, we know very little about the relative efficiencies of different collecting methods (Youngbluth 1982, Stretch 1985) since to date, no one has utilized pumps, emergence traps, and settlement traps in one area and compared catches. Second, percentages have been calculated using both instantaneous and cumulative methods. The former is essentially the fraction of the bottom fauna collected (usually with pumps) in the water above an area of substrate over a period of minutes (may be $<1 \%$, Palmer \& Gust 1985). The cumulative calculations rely on the number of animals collected, usually with emergence or sediment traps, in the water over an enclosed area during a period of 6 or more hours (may be $>50 \%$, Walters \& Bell 1986). The instantaneous method assumes that immigration equals emigration per unit of sediment, which has been verified in freshwater systems (Waters 1972). The cumulative method makes no such assumption and does not allow for emigration back into the sediments. One method is basically a measure of the number of animals drifting past a point at a given time and the other method a measure of the total number of animals migrating out of the sediments over an extended period of time.

Factors influencing the availability of meiofaunal recruits in the water column (flow, structure, taxa, disturbance) and the means by which meiofauna enter the water (active, passive) are summarized schematically in Fig. 1. The habitats listed are merely generalized examples of where active versus passive entry modes should be expected if the conditions listed in the upper column prevail. Meiofauna may enter the water column by active emergence, through passive erosion or via disturbance-induced suspension. Recruitment may be an active reentry process or a passive resettlement process governed by fluid/particle dynamics. Within the meiofauna, certain taxa will differ dramatically with respect to their ability to actively emerge and choose settlement sites. Thus, differences 


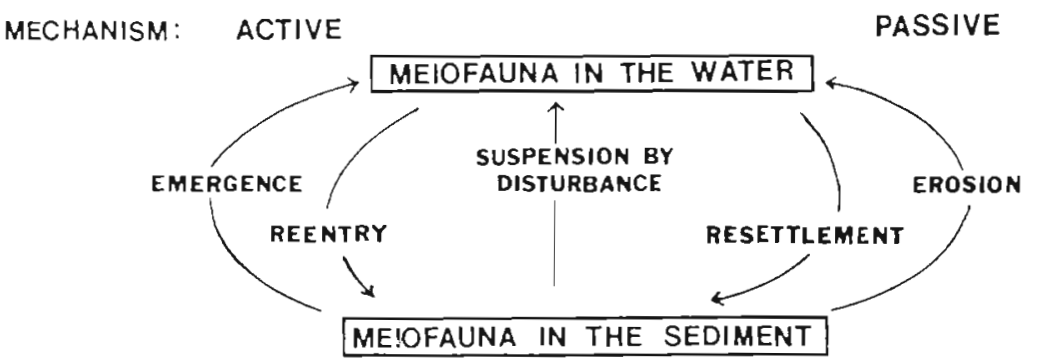

\author{
FLOW: \\ ABOVEGROUND. \\ STRUCTURE \\ TAXA: \\ DISTURBANCE:
}

LOW

PRESENT COPEPODS DOMINATE BIOLOGICAL

HABITATS :

\author{
SEAGRASS BEDS, \\ VEGETATED MARSH AREAS
}

\author{
HIGH \\ ABSENT \\ VARIABLE \\ BIOLOGICAL, PHYSICAL
UNVEGETATED MUDFLATS, SANDFLATS, BEACHES

Fig. 1. Schematic illustration of the mechanisms (active, passive) by which melofauna move between the sediments and water Four factors influencing entry are identified: flow, structure, taxonomic composition, disturbance. Habitats are listed as generalized examples where active vs passive recruitment of meiofauna are expected if the conditions listed in the factor column above the respective habitats preval

in community composition will explain some of the habitat differences in active versus passive modes of recruitment. For the meiofauna of vegetated areas, if flow is generally reduced and the fauna are capable of active swimming (e.g. dominated by copepods), our present knowledge would suggest a recruitment model involving substrate choice through active swimming. In areas which are more rigorous hydrodynamically, such as unvegetated mudflats, passive recruitment processes dominate and are modified only to a limited extent by behaviors which may reduce or enhance an organism's susceptibility to suspension and transport. Structural complexity of a habitat will influence recruitment both by altering the near-bottom flow regime and because it may be associated with enhanced active emergence by some fauna. Disturbance events may cause suspension of meiofauna in any habitat and may be associated with active emigration when the fauna can control their spatial position, i.e. under extremely low flows. In areas subjected to higher flows, disturbance events are more likely to be associated with passive transport of the meiofauna.

\section{FUTURE DIRECTIONS}

Direct laboratory observations of meiofaunal behavior at the sediment-water interface under different flow, structure and disturbance conditions would add to our understanding of active versus passive recruitment: When and how are meiofauna leaving the sediments? Are certain meiofauna residing perma- nently in the benthic boundary layer or up in the watercolumn? Do these meiofauna rely on sediment for any resource? Recently, it has been suggested that some meiofauna (e.g. the harpacticoid Zausodes), swim most of the time but may depend on the sediment for feeding (Bell pers. comm.). Should this animal be considered meiobenthic, epibenthic, or demersal? Similarly, studies have indicated that some demersal zooplankton stay close to the bottom, rarely moving far up into the water (Alldredge \& King 1980). Indeed, it may be that the meiofauna/demersal zooplankton distinction is somewhat artificial ecologically and merely represents an attempt by scientists to impose boundaries or categories where continua should be used. Clearly, complex life styles are led by some animals which were once considered infaunal. What we need now is more life-history and behavioral information to determine which meiofaunal-sized organisms live within the sediments, which actively and passively utilize the sediments and water, or which live and feed exclusively in the benthic boundary layer

Unless a species is known to spend some amount of time in the sediments (i.e. not live exclusively in the benthic boundary layer), perhaps it is best to take an ecological view of this animal as demersal or hyperbenthic (Alldredge \& King 1977, Sibert 1981, Olhorst 1982, Fleeger et al. 1983). Comparing dispersal modes of non-sediment dwellers to infaunal meiofauna just because they are similar in size (both 'meio'), leads to confusion and unnecessary speculation as to why they differ so with respect to recruitment modes. This is not to say that hyperbenthic meiofauna should be excluded 
from all meiofaunal studies. Undoubtedly, depending on the question of interest, they may be extremely important.

At this time, there is much that we do not know about meiofaunal recruitment, particularly the settlement and post-settlement stages. More studies are needed, especially ones which utilize similar methodologies in different habitats. The distances meiofauna are transported or migrate have only been estimated and direct measurements are needed. Studies designed to examine meiofaunal settlement/reentry must be carried further: What flow conditions allow active rentry? What behaviors facilitate habitat selection when flow is such that settlement is passive? Are settlement patterns responsible for the well-known patchiness of meiofauna or do post-settlement events establish patches? How do infaunal movements interact with settlement patterns? Do structures serve as a refuge from flow for numerous meiofauna or only for specific groups (e.g. laophontid harpacticoids)? If meiofauna of hydrodynamically benign seagrass areas are exposed to flow, as is expected during even moderate storms, do they burrow into the sediments and cling to structures or does passive transport then become important? These are just some of the questions that future research will undoubtedly explore. These are difficult questions to answer experimentally but are approachable with creative field designs or laboratory flume studies coupled with cinematography or direct microscopic observations.

Acknowledgements. This research was supported by grants from the National Science Foundation (OCE-8509904, RII8620422) and the Byron K. Trippet fund of Wabash College. I gratefully acknowledge discussions and critical comments from J. D. Allan, S. S. Bell, G. R. F. Hicks, D. S. Smith and 3 anonymous reviewers.

\section{LITERATURE CITED}

Alldredge, A. L., King, J. M. (1977). Distribution, abundance, and substrate preferences of demersal reef zooplankton at Lizard Island Lagoon, Great Barrier Reef. Mar. Biol. 41: $317-333$

Alldredge, A. L., King, J. M. (1980). Effects of moonlight on the vertical migration patterns of demersal zooplankton. J. exp. mar. Biol. Ecol. 44: 133-156

Ambrose, W. G. (1984). Increased emigration of the amphipod Rhepoxynius abronius (Barnard) and the polychaete Nephthys caeca (Fabricius) in the presence and absence of invertebrate predators. J. exp. mar. Biol. Ecol. 80: 67-75

Bell, S. S., Sherman, K. S. (1980). Tidal resuspension as a mechanism for meiofauna dispersal. Mar. Ecol. Prog. Ser. 3: $245-249$

Bell, S. S., Walters, K., Hall, M. O. (1987). Habitat utilization by harpacticoid copepods: a morphometric approach. Mar Ecol. Prog. Ser, 35: 59-64

Bell, S. S., Hicks, G. R. F., Walters, K. (1988). Active swimming in meiobenthic copepods of seagrass beds: species patterns and role in reproductive behavior. Mar. Biol. 98 $351-358$

Blome, P. (1983). Ökologie der Nematode eines Sandstrandes der Nordinsel Sylt. Mikrofauna des Meeresbodens 88: $1-76$

Blundon, J. A., Kennedy, V S. (1982). Refuges for infaunal bivalves from blue crab, Callinectes sapidus Rathbun, predation in Chesapeake Bay. J. exp. mar. Biol. Ecol. 65: $76-81$

Boaden, P. J. S. (1968). Water movement - a dominant factor in interstitial ecology. Sarsia 34: 125-136

Boaden, P. J. S., Platt, H. M. (1971). Daily migration patterns in an intertidal meiobenthic community. Thalassia jugosl. 7 : $1-12$

Bowden, K. R. (1978). Physical problems of the benthic boundary layer. Geophys. Surveys 3: 256-296

Butman, C. A. (1986). Larval settlement of soft-sediment invertebrates: some predictions based on an analysis of near-bottom profiles. In: Nihoul, J. C. J. (ed.) Marine interfaces ecohydrodynamics. Elsevier, Amsterdam, p. $487-513$

Butman, C. A. (1987). Larval settlement of soft-sediment invertebrates: the spatial scales of pattern explained by active habitat selection and the emerging role of hydrodynamic processes. Oceanogr. mar. Biol. A. Rev. 25: 113-165

Chandler, G. T., Fleeger, J. W. (1983). Meiofaunal colonization of azoic estuarine sediment in Louisiana: mechanisms of dispersal. J. exp. mar Biol. 69: 175-188

Coull, B. C., Bell, S. S. (1979). Perspectives of marine meiofaunal ecology. In: Livingston, R. J. (ed.) Ecological processes in coastal and marine systems. Plenum Press, New York, p. 189-216

Coull, B. C., Wells, J. B. J. (1983). Refuges from fish predation experiments with phytal meiofauna from the New Zealand rocky intertidal. Ecology 64: 1599-1609

Coull, B. C., Palmer, M. A. (1984). Field experimentation in meiofaunal ecology. Hydrobiologia 118: 1-19

Crenshaw, D. G. (1980). How interstitial animals respond to viscous flows. Ph. D. thesis, Duke University, Durham, North Carolina

Decho, A. W. (1986). Water-cover influences on diatom ingestion rates by meiobenthic copepods. Mar Ecol. Prog. Ser 33: $139-146$

Eckman, J. E. (1983). Hydrodynamic processes affecting benthic recruitment. Limnol. Oceanogr. 28: 241-257

Eckman, J. E. (1985). Flow disruption by an animal tube mimic affects sediment bacterial colonization. J mar. Res. 43: $419-435$

Eskin, R. A., Palmer, M. A. (1985). Suspension of marine nematodes in a turbulent tidal creek: species patterns. Biol. Bull mar, biol. Lab., Woods Hole 169: 615-623

Fegley, S. R. (1987). Experimental variation of near-bottom current speeds and its effects on depth distribution of sand-living meiofauna. Mar. Biol. 95: 183-191

Fleeger, J. W. (1980). Community structure of an estuarine meiobenthic copepod assemblage. Estuar coast. mar. Sci. 10: $107-117$

Fleeger, J. W., Sikora, W. B., Sikora, J. P. (1983). Spatial and long-term temporal variation of meiobenthic-hyperbenthic copepods in Lake Pontchartrain, Louisiana. Estuar. coast. Shelf Sci. 16: 441-453

Fleeger, J. W., Chandler, G. T., Fitzhugh, G. R., Phillips, F. E (1984). Effects of tidal currents on meiofauna densities in vegetated salt marsh sediments. Mar. Ecol. Prog. Ser. 19: $49-53$

Hagerman, G. M., Rieger, R. M. (1981). Dispersal of benthic 
meiofauna by wave and current action in Bogue Sound N.C., USA. P.S.Z.N. Mar. Ecol. 2: 245-270

Hannan, C. A. (1984). Planktonic larvae act like passive particles in turbulent near-bottom flows. Limnol. Oceanogr 29: 1108-1115

Hauspie, R., Polk, P. H. (1973). Swimming behavior patterns in certain benthic harpacticoids (Copepoda). Crustaceana 25: 95-193

Heck, K. L., Orth, R. J. (1980). Seagrass habitats: the roles of habitat complexity, competition, and predation in structuring associated fish and motile macroinvertebrate assemblages. In: Kennedy, V S. (ed.) Estuarine perspectives Academic Press, New York, p. 449-464

Hicks, G. R. F. (1986). Distribution and behaviour of meiofaunal copepods inside and outside seagrass beds. Mar Ecol. Prog. Ser. 31: 159-170

Hicks, G. R. F. (1988). Evolutionary implications of swimming behavior in meiobenthic copepods. Hydrobiologia (in press)

Hockin, D. C., Ollason, J. G. (1981). The colonization of artifically isolated volumes of intertidal estuarine sand by harpacticoid copepods. J. exp. mar. Biol. Ecol. 53: 9-29

Hopper, B. E., Meyers, S. P. (1966). Observations on the bionomics of the marine nematode Metoncholaimus sp. Nature, Lond. 209: 899-900

Jacobs, L. J. (1984). The free-linving inland aquatic nema todes of Africa - a review. Hydrobiologia 113: 259-291

Jensen, P. (1981). Phyto-chemical sensitivity and swimming behavior of the free-living marine nematode Chromadorita tenius. Mar. Ecol. Prog. Ser. 4: 203-206

Kern, J. C., Bell, S. S. (1984). Short-term temporal variation in population structure of two harpacticoid copepods Zausodes arenicolus and Paradactylopodia brevicornis Mar. Biol. 84: 53-63

Kern, J. C., Taghon, G. L. (1986). Can passive recruitment explain harpacticoid copepod distribution in relation to epibenthic structure? J. exp. mar. Biol. Ecol. 101: 1-23

Magnhagen, C., Wiederholm, A. M. (1982). Food selectivity versus prey availability: a study using the marine fish Pomatoschistus microps. Oecologia (Berl.) 55: 311-315

Malmqvist, B., Sjostrom, P. (1987). Stream drift as a consequence of disturbance by invertebrate predators Oecologia (Berl.) 74: 396-403

Marinelli, R. L., Coull, B. C. (1987). Structural complexity and juvenile fish predation on meiobenthos: an experimental approach. J. exp. mar. Biol. Ecol. 108: 67-81

McIntyre, A. D. (1969). Ecology of marine meiobenthos. Biol. Rev. 44: 245-290

Olhorst, S. L. (1982). Diel migration patterns of demersal reef zooplankton. J. exp. mar. Biol. Ecol. 60: 1-15

Osenga, G. A., Coull, B. C. (1983). Spartina alterniflora Loisel root structure and meiofauna abundance. J. exp. mar. Biol. Ecol. 67: 221-225

Palmer, M. A. (1984). Invertebrate drift: behavioral experiments with intertidal meiobenthos. Mar Behav. Physiol. 10: 235-253

Palmer, M. A. (1986). Hydrodynamics and structure: interactive effects on meiofauna dispersal. J. exp. mar. Biol. Ecol. 104: 53-68

Palmer, M. A. (1988). Epibenthic predators and marine meiofauna: separating predation, disturbance, and hydrodynamic effects. Ecology 69: 1251-1259

Palmer, M. A., Brandt, R. R. (1981). Tidal variation in sediment densities of marine benthic copepods. Mar. Ecol. Prog. Ser. 4: $207-212$

Palmer, M. A., Gust, G. (1985). Dispersal of melofauna in a turbulent tidal creek. J. mar. Res. 43: 179-210
Palmer, M. A., Molloy, R. M. (1986). Flow and the vertical distribution of meiofauna: a flume experiment. Estuaries 9: 225-228

Platt, H. M. (1977). Vertical and horizontal distribution of freeliving marine nematodes from Strangford Lough, Northern Ireland. Cah. Biol. mar. 18: 261-273

Reidenauer, J. A., Thistle, D. (1981). Response of a soft-bottom harpacticoid community to stingray (Dasyatis sabina) disturbance. Mar. Biol. 65: 261-267

Rhoads, D. C., Aller, R. C., Goldhaber, M. B. (1977). The influence of colonizing benthos on physical properties and chemical diagenesis of the estuarine seafloor. In: Coull, B. C. (ed.) Ecology of marine benthos. University of South Carolina Press, Columbia, p. 113-138

Robertson, A. I., Howard, R. K. (1978). Diel trophic interactions between vertically-migrating zooplankton and their fish predators in an eelgrass community. Mar. Biol. 48: $207-213$

Savidge, W. B., Taghon, G. L. (1988). Passive and active components following two types of disturbance on an intertidal sandflat. J. exp. mar. Biol. Ecol 115: 137-155

Scheltema, R. S. (1986). On dispersal and planktonic larvae of benthic invertebrates: an eclectic overview and summary of problems. Bull. mar. Sci. 39: 290-322

Scheibel, W. (1974). Submarine experiments on benthic colonization of sediments in the Western Baltic Sea 2. Meiofauna. Mar. Biol. 28: 265-268

Scheibel, W., Rumohr, H. (1979). Meiofaunaentwicklung auf künstlichen Weichböden in der Kieler Bucht. Helgoländer wiss. Meeresunters. 32: 305-312

Service, S. K., Bell, S. S. (1987). Manipulative studies of the effects of harpacticoid copepod densities on dispersal. J. exp. mar. Biol. Ecol. 114: 49-62

Sherman, K. S., Coull, B. C. (1980). The response of meiofauna to sediment disturbance. J. exp. mar. Biol. Ecol. 46: 59-71

Sibert, J. R. (1981). Intertidal hyperbenthic populations in the Nanaimo Estuary. Mar. Biol. 64: 259-265

Silvester, N. R., Sleigh, M. A. (1985). The forces on microorganisms at surfaces in flowing water. Freshwater Biol. 15: $433-449$

Statzner, B. (1981). The relation between 'hydraulic stress' and microdistribution of benthic invertebrates in a lowland running water system, the Schierenseebrooks (North Germany). Arch. Hydrobiol. 91. 192-218

Sterrer, W. (1973). Plate tectonics as a mechanism for dispersal and speciation in interstitial sand fauna. Neth. J. Sea Res. 7: $200-222$

Stretch, J. J. (1985). Quantitative sampling of demersal zooplankton: reentry and airlift dredge sample comparisons J. exp. mar. Biol. Ecol. 91: 125-136

Swedmark, B. (1963). The interstitial fauna of marine sand Biol. Rev. 39: 1-42

Thistle, D., Reidenauer, J. A., Findlay, R. H., Waldo, R. (1984). An experimental investigation of enhanced harpacticoid (Copepoda) abundances around isolated seagrass shoots, Oecologia (Berl.) 63: 295-299

Walters, K. (1987). Experimental investigations of vertically migrating meiofaunal populations in subtropical sand and seagrass habitats. Ph. D. thesis, University of South Florida, Tampa

Walters, K., Bell, S. S. (1986). Diel patterns of active vertical migration in seagrass meiofauna. Mar. Ecol. Prog. Ser. 34 95-103

Warwick, R. M., Gee, J. M. (1984). Community structure of estuarine meiobenthos. Mar. Ecol. Prog. Ser. 18: 97-111

Warwick, R. M., Collins, N. R., Gee, J. M., George, C. L. (1986). Species size distributions of benthic and pelagic 
Metazoa: evidence for interaction? Mar. Ecol. Prog. Ser. 34: $63-68$

Waters, T. F. (1972). The drift of stream insects. Ann. Rev. Entomol. 17. 253-272

Wimbush, M., Munk, W (1970). The benthic boundary layer. In: Maxwell, A E. (ed.) The sea., Vol. 4. Wiley-Interscience, Chichester, p. 731-758
Woodin, S. A. (1978). Refuges, disturbance, and community structure: a marine soft-bottom example. Ecology 59: $274-284$

Youngbluth, M. J. (1982). Sampling demersal zooplankton: a comparison of field collections using three different emergence traps. J. exp. mar Biol. Ecol. 61: 111-124

This review was submitted to the editor; it was accepted for printing on June 27, 1988 